\title{
Determinants of Microfinance Institutions Loan Portfolios Quality: Empirical Evidence from Ethiopia
}

\author{
Obsa Teferi \\ Department of Accounting and Finance, College of Business \\ and Economics Hawassa University, Ethiopia
}

\begin{abstract}
This study examines determinants of loan portfolios quality, using panel data of 15 microfinance institutions from the period 2003 to 2009 . The study employed three dependent variables as proxies for loan portfolios quality, namely: provision for loan impairment (LLR), portfolio at risk over 30 - days (PAR-30days) and write -off ratio (WOR). This study is crucial from given that there is no research on MFIs loan portfolios quality using quantitative approach in Ethiopia. Based on pooled ordinary least squares (OLS) and random effects generalized least squares, the study finds an institution size ( LnTA) is negatively and significantly influences LLR and PAR- 30 days. Outstanding loan ratio has a significant positive impact on PAR-30 days and WOR. The ratio of women borrowers (WomBor) is significantly and negatively related to LLR and WOF. Change in total loan ratio has a significant negative (unexpected sign) impact on all of MFIs portfolios risk indicators: LLR, PAR-30days and WOR. Operating expense ratio is also positively related to WRO. The study finds no any significant sign between macroeconomic factors (changes in gross national income per capital and inflation) and MFIs portfolios risk indicators: LLR, PAR-30days and WOR. The findings of the study have implications for policymakers and microfinance institutions since MFIs provide financial services to poor households, they highly face default risk when borrowers fail to repay their obligations as per the agreement. So this study provides hint on some important determinants of MFIs loan portfolio quality.
\end{abstract}

DOI: $10.7176 / \mathrm{EJBM} / 11-25-02$

Publication date:September $30^{\text {th }} 2019$

\section{Introduction}

Nowadays, microfinance institutions have been playing substantial roles in poverty reduction and employment creation, by providing credit services to poor people. It is growing and becoming a major component of most financial systems in developing countries (Daley-Harris ,2006). The role of microfinance institutions in providing financial services to those who could not be served by formal banks is found to play a major role in economy. Virtually, in providing credit services MFIs deal with poor people those who cannot provide collateral, so that their loan is less secured (Ruerd and Schers, 2007).

Since the major objective of MFIs is to serve low income society, thus do not require formal collateral and instead base loan decisions on character, group solidarity, and past repayment history. Collateral, when pledged, may not be legally registered or may have little liquidation value. Thus, when loan portfolio quality suffers substantially, MFIs face more loan portfolio risk. In the other way, the extent to which the loan will secure is based on the MFIs screen, monitor and facilitate repayment activities. The more the MFIs properly analyze and approved loan have significant impact on the loan repayment rate which in turn brings back money disbursed to clients (Crabb and Keller, 2004).

The Ethiopian microfinance sector is one of the fastest growing in the world today. Currently, it's an aggregate loan portfolios reach around 2908.7 billion in birr from 1622 billion birr in 2005 (www.themixmarket.com) . The vital objective of Ethiopian microfinance is poverty alleviation. To do so, their loan portfolio should be secured, and can be collected in order to facilitate loan disbursement to clients. Despite the increasing reliance on microfinance institutions to reduce poverty in Ethiopia, to my knowledge there has no research done related determinants of MFIS loan portfolio quality. In an attempt to fill this gap, this study analyzes 15 MFIs data set using panel regression. I look at ten independent variables that may have an impact on the quality of the portfolio, such as the size of an institution, leverage, years of experience, productivity, operating expense, changes in total loan ratio, outstanding loan ratio, the ratio of women borrower as the firm characteristics and macroeconomic factors, namely, changes in gross national income per capital and inflation.

This study intends to examine determinants of MFIs loan portfolio quality. To measure loan portfolio quality, I used three variables: provision for loan impairment (LLR), portfolio at risk over 30 days (PAR-30 days) and write- off ratio (WOR). Therefore, the study employed three models to test MFIs portfolio quality. For model one in which provision for loan impairment used as dependent variable, estimations are made using the pooled ordinary least squares (OLS). The random effects model is used for the rest two models. The findings of this research contribute to the microfinance literature by examining determinants of MFIs loan portfolio which has been less explored in prior studies. The study has several limitations: first there are missing points on MIX market data set that I used, because some MFIs do not regularly report on MIX market. These missing points may bias the results. 
Second some variables like lending methodology, interest rate, financial depth are not included in the model. Finally, the study used non-random sampling approach which somewhat limits generalization of the findings.

\section{Literature Review}

\section{What is Microfinance Institutions?}

Microfinance institution has been defined by many researchers and organizations in different aspects, for example, Otero (1999) defines it as the provision of financial as services to the poor people with micro and small enterprises. Robinson (2001) defines it as small scale financial services primarily credit and saving provided to people who farm or fish or herd who operate small enterprises or microenterprises. Arsyad (2005) defines it as the provision of financial services (generally saving and credit) to low income clients. The way in which these authors define microfinance institution seems different but the essence is that microfinance provides credit to the poor and low income households that don't have access to commercial banks. Practically, commercial banks consider the poor people as unbankable due to their lack of collateral and information asymmetries.

As microfinance institutions deal with providing financial services to poor people those who cannot bring formal collateral, its loan is less secured. Most MFIs do not require formal collateral, and instead base loan decisions on character, group solidarity, and past repayment history. Collateral, when pledged, may not be legally registered or may have little liquidation value. Thus, when loan portfolio quality suffers substantially, MFIs face far greater loan losses (Ruerd and Schers (2007). Besides this concept, prior studies have suggested several determinant factors of MFI loan portfolio. Peter and Keller (2004) found that the ratio of women borrowers within the total client has relationship with MFIs loan portfolio. They also suggest that in group lending approach which is most likely used when the MFI is lending to women reduces risk in the portfolio. Zeller (1998) find that groups consisting of members facing homogenous risk exposure do not have higher repayment rates and therefore reduce risks in loan portfolios. Basically, one the main objectives of many microfinance institutions is to provide credit services to women in the poorest groups because women have special barriers that men do not face (Ledgerwood, 1999).

Ruerd and Schers (2007) and Gonzalez (2007) argue that MFI size exercises an opposite relationship on the Portfolio at Risk. The larger MFIs tend to reduce portfolio risk because they appear though to be better able to diversify loan risks. In fact, larger firms are subject to various investigations by financial analysts, regulators, external auditors and they relatively hire more qualified employees which in turn reduce the risk of loan (Zoubi and Al-Khazali, 2007). The larger MFIs relatively enjoy economic of scale than the smaller. Gonzalez (2007) provide an evidence that productivity (the number of borrowers per staff member) and operating expense ratio have significant relationship with MFI loan portfolio quality as measured by portfolio at risk over 30 days and write -off ratio. Basically, actual client screening and portfolio monitoring cannot be measured, so that productivity is the proxy for both. In line with this notion, it is clear that a low borrower to staff ratio would argue more time spent on screening and monitoring borrowers than higher ratio. Operating expense ratio captures differences among MFIs in cost structures and it measures efficiency of MFIs. It is can be expected that more efficient MFIs tend to have lower loan portfolio risk.

The empirical evidences on the relationship between leverage and portfolio risk is limited. Leverage measures the degree to which a MFI borrows money relative to its equity. Abdelghany (2005) finds that high leverage firms more likely to face portfolio risk as measured by provision for loan impairment ratio. The most widely used measure of leverage is the debt to equity ratio. The literature (e.g, Gonzalez, 2007) suggests firm age as the determinant of MFIs loan portfolio quality. The MFI with long operating life have more experience in screening, monitoring and collection practices than MFI at an infant level. Change in total loan ratio and outstanding loan ratio are also suggested as the major determinants of loan portfolios quality. Since these variables are pertained to default risk. An increase in total loans may result from an increase of changes of the aggregate demand for loan and/ or liberal credit policies with lower credit standards requirement by manager (Berger and Udell, 2003). These origins of changes in total loans are associated with higher default risk. Therefore, the higher growth of total loans may result in lower higher loan portfolio risk. The MFIs are also different in asset diversification which is measured by total outstanding ratio to total assets. A MFI with high proportion of loan portfolio to its total assets is more likely to have higher loan portfolio risk because the magnitude of loans default increase with the size of loan outstanding.

Prior studies argue that macroeconomic factors (changes in gross national income (GNI) and inflation) have impact on MFI loan portfolio quality. If the overall economy rises, the risk of the portfolio will decline. Gonzalez (2007) suggests that when economic conditions are more favorable for MFIs they are willing to increase the risk of their portfolios, and do so without deteriorating the overall quality of their portfolios as measured by loan loss ratio and write -off ratio. If the inflation rate raises, particularly to hyper-inflation levels, the risk of the portfolio rises. More clearly, higher inflation increases the risk of default in the loan portfolio. Brownbrigde (1998) argue that high inflation makes loan appraisal more difficult because the viability of potential borrowers depends up on unpredictable growth in the overall inflationary rate. In inflationary economy, borrowers may not repay their debt 
and thus loan portfolio risk will rise. Conversely, higher inflation may help the borrower if they originally obtained fixed rate loans dominated in local currency. Based on these empirical results, the study has developed two hypotheses as follow:

H1: MFI characteristics are significantly related to loan portfolios quality

H2: Macroeconomics factors (change in GNI per capital and inflation) have a significant association with MFI loan portfolios quality

\section{Objective of the study}

This study examines determinants of microfinance institutions (MFI) loan portfolios quality as measured by three indicators of portfolio risk: Loan loss ratio (LLR), portfolio at risk over 30 days (PAR-30) and write-off ratio (WOR). Specifically, it aims at achieving the following objectives:

- To scrutinize the effect of MFI characteristics on loan portfolio quality

- To examine the effect of macroeconomics factors (change in GNI per capital and inflation) on MFI loan portfolio quality

\section{Research methodology \\ Sample and sampling techniques}

As reported by National Bank of Ethiopia, currently there are 33 microfinance institutions in Ethiopia. However, only 23 MFIs are available in the MIX market website to which I have accessed their data. As the MFIs with the required data are limited, I selected MFI with seven years financial data and excluded MFI with less than seven years operating life. Specifically, fifteen MFIs were selected based on judgmental sampling.

\section{Data}

The study used secondary data accessed from the MIX Market Inc. website (www.themixmarket.com). The time period covered is from 2003 to 2009. The Mix Market is a not-for profit initiative that works in for the dissemination of information among the MFIs institutions. The data on Gross National Income (GNI) was accessed from the website (www.indexmundi.com/facts/ethiopia/gni-per-capita) and inflation was taken from National bank of Ethiopia.

\section{Model specification}

The literature suggests four indicators of portfolio quality ( e.g, Gonzalez, 2007) i'e, portfolio at risk over 30 days, portfolio at risk over 90 days, loan loss ratio and write -off ratio. The first two variables are assumed to measure portfolio at risk and the later are deemed to measure default risk. Following this scenario, the study employed loan loss rate as measured by provision for loan impairment divided by total assets, portfolio at risk over 30 days ratio and write - off ratio as proxies for portfolio quality. Due to data unavailability, I have not used portfolio at risk over 90 days. Therefore, I run the following three panel regression models.

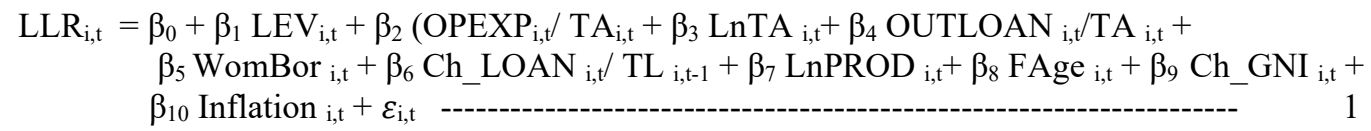

PAR-30 days ditt $_{i, t, t}=\beta_{0}+\beta_{1}$ LEV $_{i, t}+\beta_{2}\left(\right.$ OPEXP $_{i, t} /$ TA $_{i, t}+\beta_{3}$ LnTA $_{i, t}+\beta_{4}$ OUTLOAN $_{i, t} /$ TA $_{i, t}+$ $\beta_{5}$ WomBor $_{\mathrm{i}, \mathrm{t}}+\beta_{6}$ Ch_LOAN $_{\mathrm{i}, \mathrm{t}}$ TL $_{\mathrm{i}, \mathrm{t}-1}+\beta_{7}$ LnPROD $_{\mathrm{i}, \mathrm{t}}+\beta_{8}$ FAge $_{\mathrm{i}, \mathrm{t}}+\beta_{9}$ Ch_GNI $_{\mathrm{i}, \mathrm{t}}+$ $\beta_{10}$ Inflation $_{\mathrm{i}, \mathrm{t}}+\varepsilon_{\mathrm{i}, \mathrm{t}}$

WOR $_{i, t}=\beta_{0}+\beta_{1}$ LEV $_{i, t}+\beta_{2}\left(\operatorname{OPEXP}_{\mathrm{i}, \mathrm{t}} / \mathrm{TA}_{\mathrm{i}, \mathrm{t}}+\beta_{3} \operatorname{LnTA}_{\mathrm{i}, \mathrm{t}}+\beta_{4} \operatorname{OUTLOAN}_{\mathrm{i}, \mathrm{t}} / \mathrm{TA}_{\mathrm{i}, \mathrm{t}}+\right.$ $\beta_{5}$ WomBor $_{\mathrm{i}, \mathrm{t}}+\beta_{6}$ Ch_LOAN $_{\mathrm{i}, \mathrm{t}} / \mathrm{TL}_{\mathrm{i}, \mathrm{t}-1}+\beta_{7}$ LnPROD $_{\mathrm{i}, \mathrm{t}}+\beta_{8}$ FAge $_{\mathrm{i}, \mathrm{t}}+\beta_{9}$ Ch_GNI $_{\mathrm{i}, \mathrm{t}}+$ $\beta_{10}$ INFL $_{i, t}+\varepsilon_{i, t}$

Where:

$\mathrm{i}=$ microfinance index

$\mathrm{t}=$ year index

LLR $=$ Loan loss ration as measured by provision for loan impairment divided by total assets

PAR-30days = loans with more than 30 days of delayed payment divided by total assets

$\mathrm{WOR}=$ write- off ratio

$\mathrm{TA}=$ total assets

$\mathrm{TL}=$ Total loan outstanding loan at year $\mathrm{t}-1$

$\mathrm{LEV}=$ debt to equity ratio

OPEXP $=$ total operating expense divided by total assets 
LnTA $=$ natural logarithm of total assets as the proxy of MFIs size

OUTLOAN = total outstanding loan divided by total assets

WomBor $=$ percentage of women borrower within total borrowers

Ch_LOAn $=$ change in loan ratio

$\mathrm{Ln} \overline{\mathrm{P}} \mathrm{ROD}=$ natural logarithm of productivity as measured by number of borrowers per staff member

FAge $=$ firm age

Ch_GNI = percentage change in Gross National Income per capital

$\mathrm{INFL}=$ general inflation rate

\section{Results}

Table 1 presents the descriptive statistics (minimum, mean, maximum and variance) of all variables of the study. The mean of loan loss ratio is (1.7543), whereas the minimum, maximum and variance are -.01, 9.56, and 3.515. When looking at PAR -30 days, WOR, Leverage, and OPEXPR, their variances are significantly exceed their means. This suggests that there is a significant variation among the sample micro finance institutions and over the observation period on these variables. Similar, the variance coefficients on total asset the measure of MFI size change in GNI per capital and inflation are greater than their means. Some microfinance institutions are very high in size as compared to others; therefore, the larger MFIs may enjoy economics of scale.

Table 1 Descriptive Statistics

\begin{tabular}{|l|r|r|r|r|r|}
\hline Variable & Sample & \multicolumn{1}{c|}{ Minimum } & Maximum & \multicolumn{1}{c|}{ Mean } & \multicolumn{1}{c|}{ Variance } \\
\hline LLR & 77 & -.01 & 9.59 & 1.7543 & 3.515 \\
\hline PAR-30days & 83 & .13 & 37.31 & 7.2254 & 69.080 \\
\hline WOR & 49 & .00 & 13.83 & 1.8796 & 7.949 \\
\hline LEV & 97 & .01 & 8.56 & 1.8918 & 2.716 \\
\hline OPEXR & 84 & 1.85 & 40.98 & 10.6807 & 44.113 \\
\hline FIRMSIZE & 98 & 196914 & 197847309 & 23488953.82 & 2114423939444769 \\
\hline OUTLOAN & 98 & .28 & .94 & .7304 & .014 \\
\hline WomBor & 85 & .10 & .93 & .5021 & .037 \\
\hline Ch_LOAN & 94 & -.29 & 3.56 & .5208 & .357 \\
\hline FAge & 105 & 2 & 12 & 7.33 & 2.397 \\
\hline PROD & 89 & 47 & 388 & 181.92 & 3720.323 \\
\hline Ch_GNI & 105 & -4.33 & 10.67 & 6.7414 & 21.802 \\
\hline INFL & 105 & 2.82 & 58.45 & 18.9357 & 285.571 \\
\hline
\end{tabular}

Table 2 reports the Person correlation coefficients of three dependent and ten independent variables. As can be observed from the table, PAR- 30days has a significant positive correlation with Loan Loss Ratio (LLR). The coefficient on WOR also shows a significant positive association with LLR. The three dependent variables (LLR, PAR-30 days and WOR) are significantly and positively correlated to each other. This argues that a firm with higher portfolio risk at over 30 days would have a high loan loss ratio and write-off ratio. The LnTA is negatively and significantly correlated with LLR, PAR-30 days and WOR. It implies the the larger MFIs have less likely portfolio risk than small in size. The larger firms are subject to various scrutinize from analysts and relatively hire high qualified employees which in turn reduces portfolio risk. Productivity as measured by number of borrowers per staff member has a negative significant correlation with LLR and PAR-30 days and positive with WOR.

\section{Estimation Method}

To decide on the panel regressions models that is whether the random effects or fixed effects fit for the data, the study used Hausman specification test. The Hausman test was run and the output demonstrate p- value .0582 for model 1 and .9674 for model 2. The Breusch-Pagan Lagrangian multiplier test was also used to fix on whether a random effects or ordinary least squares (OLS) regression is appropriate. The results from the test shows insignificant p-value .7747 for model 1 and significant $p$ - value .000 for model 2.Accordinglly, the ordinary least squares is found fitting for Model 1whereas the random effects fit for model 2. In model three I face doubt in running the Hausman test, it ignored to show result. Therefore, I decide to select the estimation using the BreuschPagan Lagrangian multiplier test and the result from the test suggests that the ordinary least square is appropriate.

\section{Testing OLS Assumptions}

The classical linear regression model is subject to several important assumptions for example multicollineartiy, heteroskedasticty and normal distribution of residuals. Accordingly, I measure the degree of multicollinearity using Variance inflation factors (VIF) suggested in the rule-of-thumb. As per this threshold if the variance inflation 
factor on each variable is less than ten, multicollinearity is not a serious concern. In this study, the assumption is met (see, appendex). I test heteroskedasticty using Breusch- Pagan which test the hypothesis that constant variance. The results from the test for the three models reveal the presence of heteroskedasticty. To control for this concern, I used cluster robust standard error which overcome the effect of violation of this assumption. The normal distribution of residual is tested using Shapiro- Wilk test for normality, it tests the hypothesis that residuals are normally distributed. The tests display insignificant $\mathrm{p}$-values on the three models; therefore I conclude that residuals have a normal distribution pattern.

\section{Regression Results}

Table 3 reports the regression results obtained from the three models in which LLP, PAR-30 days and WOR are used as dependent variables. Model 1 is significant at $F=3.38, d f=10, p$-value $<0.01$; Model 2 is significant at Wald chi $2=73.79, d f=10$, $p$-value $<0.01$, and Model 3 is significant at $F=5.48, d f=10$, $p$-value $<0.0$. As can be observed in Table 3, natural logarithm of total assets (LnTA) the proxy of MFIs size is positively and negatively related to provision for loan impairment (LLR) and portfolio at risk over 30 days (PAR-30). It implies that MFI size negatively influences portfolio risk. In fact, larger firms are subject to various investigations by financial analysts, regulators, external auditors and they relatively hire more qualified employees which in turn reduced the risk of loan (Zoubi and Al-Khazali, 2007). Ruerd and Schers (2007) also find that MFI size tends to reduce portfolio risk because larger MFIs appear though to be better able to diversify loan risks. Accordingly, this result suggests that larger MFIs tend to have less provision for loan impairment (LLR) and PAR-days. I found no significant relation between LnTA and write -off ratio (WOR).

The coefficient for the ratio of women borrowers within the total borrowers (WomBor) shows a negative significant relationship with provision for loan impairment ratio (LLR) and write -off ratio (WOR), implies that firms with higher ratio of women borrowers is more likely to have less provision for loan impairment and writeoff. Virtually, the primary objective of microfinance institutions is to provide credit services to poor people particularly to women through individual or group lending system. Currently, the majority of Ethiopian microfinance borrowers have access to loans through group lending system, which is inversely related to risk of loan. Group lending creates incentives for individual group members to screen and monitor other members of the group and to enforce repayment in order to reduce the risk of having to contribute to the repayment of loans of others (Peter and Keller, 2004). In this notion, the result argues that the extent of women borrower in group is adversely related to the risk of loan. The ratio of women borrower is positively related to PAR-30 days, but statistically insignificant. The coefficient on change in loan (Ch_LOAN) is negative and significant for the three indicators of portfolio risk: LLR, PAR-30 days and WOR, meaning that firms with higher change in loan tend to better control portfolio risk. As change in loan raise, MFIs take more effort to reduce portfolio risk via better screening and monitoring their borrowers. The ratio of operating expense (OPEXP) shows a significant positive relation with only WRO, suggesting that more efficient MFIs tend to have lower WOR. 
Table 3: Regression Results

\begin{tabular}{|c|c|c|c|c|c|c|}
\hline & Dependent & ariables : L & PAR-30 da & WOR & & \\
\hline$V A R I A B L E$ & LLR ( Mo & I1) & PAR-30 d & ( Model 2) & WOR ( M & el 3) \\
\hline & $\beta$ & t-value & $\beta$ & z-value & $\beta$ & t-value \\
\hline Constant & $\begin{array}{l}12.23863 \\
(4.238846)\end{array}$ & $\begin{array}{l}2.89 \\
(0.006)\end{array}$ & $\begin{array}{l}18.56738 \\
(9.647371)\end{array}$ & $\begin{array}{l}1.92 \\
(0.054)^{*}\end{array}$ & $\begin{array}{l}-9.942755 \\
(9.733725)\end{array}$ & $\begin{array}{l}-1.02 \\
(0.317)\end{array}$ \\
\hline$L E V$ & $\begin{array}{l}.135977 \\
(.1307073)\end{array}$ & $\begin{array}{l}1.04 \\
(0.303)\end{array}$ & $\begin{array}{l}.5278302 \\
(.6143821)\end{array}$ & $\begin{array}{l}0.86 \\
(0.390)\end{array}$ & $\begin{array}{l}.1430513 \\
(.1586589)\end{array}$ & $\begin{array}{l}0.90 \\
(0.376)\end{array}$ \\
\hline OPEXP & $\begin{array}{l}.0524503 \\
(.0365161)\end{array}$ & $\begin{array}{l}1.44 \\
(0.157)\end{array}$ & $\begin{array}{l}.1620611 \\
(.1666779)\end{array}$ & $\begin{array}{l}0.97 \\
(0.331)\end{array}$ & $\begin{array}{l}.3535929 \\
(.105245)\end{array}$ & $\begin{array}{l}3.36 \\
(0.003) * * *\end{array}$ \\
\hline $\operatorname{LnTA}$ & $\begin{array}{l}-.4117441 \\
(.1624918)\end{array}$ & $\begin{array}{l}-2.53 \\
(0.014)^{* *}\end{array}$ & $\begin{array}{l}-1.344642 \\
(.3832034)\end{array}$ & $\begin{array}{l}-3.51 \\
(0.000)^{* * *}\end{array}$ & $\begin{array}{l}.2558177 \\
(.2104348)\end{array}$ & $\begin{array}{l}1.22 \\
(0.235)\end{array}$ \\
\hline OUTLOAN & $\begin{array}{l}2.664986 \\
(1.894057)\end{array}$ & $\begin{array}{l}1.41 \\
(0.166)\end{array}$ & $\begin{array}{l}13.02924 \\
(6.456532)\end{array}$ & $\begin{array}{l}2.02 \\
(0.044) * *\end{array}$ & $\begin{array}{l}10.10428 \\
(3.968665)\end{array}$ & $\begin{array}{l}2.55 \\
(0.017)^{* *}\end{array}$ \\
\hline WomBor & $\begin{array}{l}-2.590752 \\
(1.267369)\end{array}$ & $\begin{array}{l}-2.04 \\
(0.046) * *\end{array}$ & $\begin{array}{l}5.19636 \\
(5.221762)\end{array}$ & $\begin{array}{l}1.00 \\
(0.320)\end{array}$ & $\begin{array}{l}-5.574871 \\
(2.252645)\end{array}$ & $\begin{array}{l}-2.47 \\
(0.020)^{* *}\end{array}$ \\
\hline Ch_LOAN & $\begin{array}{l}.998384 \\
(.3747738)\end{array}$ & $\begin{array}{l}-2.66 \\
(0.010)^{* * *}\end{array}$ & $\begin{array}{l}-3.772652 \\
(1.697409)\end{array}$ & $\begin{array}{l}-2.22 \\
(0.026)^{* *}\end{array}$ & $\begin{array}{l}-1.268517 \\
(.7175278)\end{array}$ & $\begin{array}{l}-1.77 \\
(0.089)^{*}\end{array}$ \\
\hline LnPROD & $\begin{array}{l}-1.170548 \\
(.8018634)\end{array}$ & $\begin{array}{l}-1.46 \\
(0.151)\end{array}$ & $\begin{array}{l}-1.642437 \\
(2.584043)\end{array}$ & $\begin{array}{l}-0.64 \\
(0.525)\end{array}$ & $\begin{array}{l}.3306106 \\
(1.09953)\end{array}$ & $\begin{array}{l}0.30 \\
(0.766)\end{array}$ \\
\hline FAge & $\begin{array}{l}.1140796 \\
(.1825161)\end{array}$ & $\begin{array}{l}0.63 \\
(0.535)\end{array}$ & $\begin{array}{l}.4674994 \\
(.4948248)\end{array}$ & $\begin{array}{l}0.94 \\
(0.345)\end{array}$ & $\begin{array}{l}-.2729096 \\
(.2371811)\end{array}$ & $\begin{array}{l}-1.15 \\
(0.261)\end{array}$ \\
\hline Ch_GNI & $\begin{array}{l}.0398475 \\
(.053887)\end{array}$ & $\begin{array}{l}0.74 \\
(0.463) \\
\end{array}$ & $\begin{array}{l}-.0059582 \\
(.1025529)\end{array}$ & $\begin{array}{l}-0.06 \\
(0.954)\end{array}$ & $\begin{array}{l}-.0790695 \\
(.1844587)\end{array}$ & $\begin{array}{l}-0.43 \\
(0.672)\end{array}$ \\
\hline$I N F L$ & $\begin{array}{l}-.0090099 \\
(.0137203) \\
\end{array}$ & $\begin{array}{l}-0.66 \\
(0.514) \\
\end{array}$ & $\begin{array}{l}.033304 \\
(.0341046)\end{array}$ & $\begin{array}{l}0.98 \\
(0.329) \\
\end{array}$ & $\begin{array}{l}.0265723 \\
(.0197554)\end{array}$ & $\begin{array}{l}1.35 \\
(0.191) \\
\end{array}$ \\
\hline & $\begin{array}{l}\mathrm{F}(10,50) \\
\text { Prob }>\mathrm{F} \\
\text { R-squared } \\
\text { Root MSE }\end{array}$ & $\begin{array}{c}3.38 \\
0.0000 \\
0.3723 \\
=1.5295\end{array}$ & $\begin{array}{l}\text { R-squared } \\
\text { Wald chi2( } \\
\text { Prob }>\text { chi2 }\end{array}$ & $\begin{array}{l}1760 \\
=\quad 73.79 \\
=0.0000\end{array}$ & $\begin{array}{l}F(10, \quad 25) \\
\text { Prob > F } \\
\text { R-squared } \\
\text { Root MSE }\end{array}$ & $\begin{array}{c}5.48 \\
0.0000 \\
0.6727 \\
=1.8266\end{array}$ \\
\hline
\end{tabular}

Note: Numbers in parentheses under the coefficient $(\beta)$ and $t$-value or $z$-value are robust standard errors and p-values, respectively. $*, * *$, and $* * *$ indicate statistical significance at the 10 percent, 5 percent, and 1 percent levels, respectively.

Where: Where: LLR - Loan loss ration as measured by provision for loan impairment divided by total assets; PAR-30days - loans with more than 30 days of delayed payment divided by total assets; WOR- write of ratio ; TA - total assets; TL - Total loan outstanding loan at year t-1; LEV - debt to equity ratio; OPEXP - total operating expense divided by total assets; LnTA - natural logarithm of total assets as the proxy of MFIs size; OUTLOAN - total outstanding loan divided by total assets; WomBor - percentage of women borrower within total borrowers; Ch_LOAN -change in loan ratio; LnPROD - natural logarithm of productivity as measured by number of borrowers per staff member; FAge - firm age; Ch_GNI - percentage change in Gross National Income per capital; INFL - general inflation rate.

As shown in Table 3, the study found a significant positive coefficient for outstanding loan ratio with portfolio at risk over 30 days (PAR-30 days) and WOR, reflecting that a MFI with high proportion of loan portfolio to its total assets is more likely to have higher portfolio risk because the magnitude of loan default increases with the size of loan outstanding. No significant relation is found between outstanding loan ratio and provision for loan impairment ratio (LLR). The study did not observe significant coefficient on leverage, productivity (LnPROD) for indicators of portfolio quality: LLR, PAR-30 days and WRO. Similar, macroeconomic factors (change in gross national income percapital ( Ch-GNI) and inflation) have insignificant relationship with none of MFIs portfolio quality indicators ( LLP, PAR-30 days and WOR). This means MFIs portfolio quality is not significantly response to the change in gross national income and inflation.

\section{Conclusion}

This study examines determinants of MFIs loan portfolio quality as measured by loan loss ratio (LLR), portfolio at risk over 30-days (PAR-30 days) and write- off ratio (WOR), using 7 years data of 15 Ethiopian microfinance institutions over the period 2003 to 2009 . Based on OLS and random effects estimates, the study finds a significant negative relationship between an institution size (LnTA) and LLR and PAR-30 days. It suggests a larger MFI tends with a lower portfolio risk because they appear better experience in screening, monitoring and collection activities. The findings show outstanding loan ration positively and significantly impacts PAR-30 days and WOR. It implies 
a MFI with high proportion of outstanding loans to its total asset is found have high portfolio risks. The magnitude of loan risk magnifies with outstanding loan. The coefficient for the ratio of women borrower (WomBor) reveals a significant negative impact on LLR and WOR, suggesting the extent to which MFIs make loan to women is adversely related to its loan portfolios risk. The estimates also show a significant inverse relation between changes in total loan and the three indicators of MFIs loan portfolio risk: LLR, PAR -30 days and WOR. Operating expense ratio, the measure of efficiency is positively related to WOR, reflecting the more efficient MFI is likely to have lower WOR. The study did not observe any significant relationship between macroeconomic factors ( changes in gross national income per capital (Ch_GNI) and Inflation) and MFIs portfolio risks indicators: LLR, PAR-30 days and WOR.

Overall, this analysis shows that there are many unobserved variables that are important for explaining variability of portfolio risk. MFIs portfolio risks are related to their management and human resources, governance, credit policy, interest rate, infrastructure (lack of roads or remoteness), lending methodology (Gonzalez, 2007). These are very important factors but due to data unavailability, they are not incorporated into the current analysis.

\section{References}

Abdelghany E.K. (2005). Measuring the quality of earnings” Managerial auditing Journal, VOl.20 No.9,pp.1001 $-1015$.

Arsyad L. (2005) An assessment of performance and sustainability of Microfinance Institutions: A case study of Village credit institutions in Gianyar, Bali, Indonesia, unpublished $\mathrm{PhD}$ thesis, Flinders University, Australia

Brownbrigde M. ( 1998). The cause of financial distress in local banks in Africa and implication for prudential policy, UNCTAD/OSG/DP/132.

Crabb R.P. and Keller T. (2004) . A Test of Portfolio Risk in Microfinance Institutions. Available at : http:// www.ojj.lib.byu.edu/spc/index.php/ESr/article/viewFile/1374/1335. Accessed in June, 2012

Gonzalez, Adrian (2007). Resilience of Microfinance to National Macroeconomic Events: An Econometric Analysis of MFI asset quality. The MicroBanking Bulleting, No. 14, pp. 36-38.

Ledgerwood, J. (1999), Sustainable Banking with the Poor Microfinance Handbook: An Institutional and Financial Perspective, the World Bank, Washington, DC.

Robinson, M. (2001). The Microfinance Revolution: Sustainable Banking for the Poor, Washington, DC: The World Bank.

Ruerd R. and Schers S. (2007). Microfinance portfolio performance : an explorative analysis of determinants of outreach, sustainability and risk . Available at: : http://www.themix.org, Accessed in June, 2012

Zeller, M. (1998), —Determinants of repayment performance in credit groups: the role of program design, intragroup risk pooling, and social cohesion in Madagascarl, Economic Development and Cultural Change, 46(3): p.p. 599-621.

Zoubi A. T. and Al- Khazali O. (2007), "Empirical testing of the loss provisions of banks in the GCC region" Managerial Finance, Vol. 33 No. 7, pp. 500-51

Appendix

Table 2 Pearson Correlation Coefficient

\begin{tabular}{|c|c|c|c|c|c|c|c|c|c|c|c|c|c|}
\hline Variables & $L L R$ & PAR 30 & WOR & $L E V$ & OPEXP & LnTA & OUTLOAN & WomBor & CH_LOAN & LnPROD & FAge & Ch_GNI & INFL \\
\hline$L L R$ & 1 & & & & & & & & & & & & \\
\hline$P A R-30$ & 0.4174 & 1 & & & & & & & & & & & \\
\hline WOR & 0.2696 & 0.1979 & 1 & & & & & & & & & & \\
\hline$L E V$ & 0.0084 & 0.065 & -0.1014 & 1 & & & & & & & & & \\
\hline OPEXP & 0.1633 & 0.0713 & 0.4287 & -0.4088 & 1 & & & & & & & & \\
\hline LnTA & -0.313 & -0.24 & -0.1681 & 0.3426 & -0.6985 & 1 & & & & & & & \\
\hline OUTLOAN & 0.0134 & -0.1807 & 0.162 & 0.1322 & -0.3823 & 0.3403 & 1 & & & & & & \\
\hline WomBor & -0.0558 & -0.0962 & 0.0943 & -0.3821 & 0.4688 & -0.4072 & -0.0231 & 1 & & & & & \\
\hline$C H L O A N$ & -0.1825 & -0.0585 & -0.0816 & -0.1462 & 0.1188 & -0.1711 & -0.0664 & 0.0587 & 1 & & & & \\
\hline $\operatorname{Ln} \bar{P} R O D$ & -0.2976 & -0.339 & 0.4456 & 0.1766 & -0.2011 & 0.435 & -0.0876 & -0.2878 & 0.1298 & 1 & & & \\
\hline FAge & -0.0053 & 0.2519 & -0.2687 & 0.1307 & -0.2261 & 0.0546 & -0.286 & -0.3741 & 0.2588 & 0.3266 & 1 & & \\
\hline Ch GNI & 0.0767 & -0.0229 & -0.211 & 0.0515 & -0.0587 & -0.1116 & 0.0686 & -0.1255 & 0.3205 & 0.1249 & 0.3642 & 1 & \\
\hline$I N F L$ & 0.0148 & 0.0347 & 0.0009 & -0.0657 & -0.0539 & -0.1909 & -0.3288 & -0.1673 & 0.2056 & 0.0495 & 0.4602 & 0.0708 & 1 \\
\hline
\end{tabular}

Note: a. Bolds denote significant at the $1 \%$ level

b. Italics denote significant at the $5 \%$ level 


\section{Test for Fixed Effects Versus Random Effects}

a. Model 1

Hausman Test to fix on Fixed effects or Random effects

- hausman fe re

\begin{tabular}{|c|c|c|c|c|}
\hline & \multicolumn{2}{|c|}{ - Coefficie } & \multirow[b]{2}{*}{$\begin{array}{c}(b-B) \\
\text { Difference }\end{array}$} & \multirow[b]{2}{*}{$\begin{array}{c}\operatorname{sqrt}\left(d i a g\left(V \_b-V \_B\right)\right) \\
\text { S.E. }\end{array}$} \\
\hline & $\begin{array}{l}\text { (b) } \\
\text { fe }\end{array}$ & $\begin{array}{l}\text { (B) } \\
\text { re }\end{array}$ & & \\
\hline LEV & .3604271 & .1957049 & .1647222 & .1485959 \\
\hline OPEXP & -.1214352 & .001333 & -.1227682 & .0523739 \\
\hline LnTA & -2.624654 & -.6213105 & -2.003343 & .9823962 \\
\hline OUTLOAN & 1.851722 & 2.412158 & -.5604354 & 1.62404 \\
\hline WomBor & -2.718704 & -1.865555 & -.853149 & 1.508534 \\
\hline Ch_Loan & -.4137613 & -.899699 & .4859377 & .3052538 \\
\hline PRODUCTIVITY & 1.365997 & -.3610856 & 1.727082 & .8010248 \\
\hline FAge & -.7138882 & .0403508 & -.754239 & .3558649 \\
\hline Ch_GNI & .0270572 & .0252794 & .0017779 & .0194798 \\
\hline INFLATION & -.0173031 & -.0109724 & -.0063307 & .0075441 \\
\hline
\end{tabular}

$\mathrm{b}=$ consistent under $\mathrm{HO}$ and $\mathrm{Ha}$; obtained from xtreg $\mathrm{B}=$ inconsistent under $\mathrm{Ha}$, efficient under $\mathrm{Ho}$; obtained from xtreg

Test: Ho: difference in coefficients not systematic

$$
\begin{aligned}
& \begin{aligned}
\operatorname{chi} 2(10) & =(b-B)^{\prime}\left[\left(V_{-} b-V_{-} B\right) \wedge(-1)\right](b-B) \\
& =17.81
\end{aligned} \\
& \begin{array}{ll}
\text { Prob }>\text { chi2 }= & 17.81 \\
\text { (V } & 0.0582
\end{array} \\
& \text { (V_b-V_B is not positive definite) }
\end{aligned}
$$

(b) Model 2

\begin{tabular}{|c|c|c|c|c|}
\hline & $\begin{array}{c}\text { (b) } \\
\text { fe }\end{array}$ & $\begin{array}{r}\text { ients } \\
\text { (B) } \\
\text { re }\end{array}$ & $\begin{array}{c}(b-B) \\
\text { Difference }\end{array}$ & $\begin{array}{c}\operatorname{sqrt}\left(\text { diag }\left(V_{-} \_b-V_{-} B\right)\right. \\
\text { S.E. }\end{array}$ \\
\hline $\begin{array}{r}\text { LEV } \\
\text { OPEXP } \\
\text { LnTA } \\
\text { OUTLOAN } \\
\text { WOMBOr } \\
\text { Ch_LOan } \\
\text { PRODUCTIVITY } \\
\text { FAge } \\
\text { Ch_GNI } \\
\text { INFLATION }\end{array}$ & $\begin{array}{r}.4311867 \\
.1241418 \\
-3.535262 \\
10.5986 \\
7.431118 \\
-3.009825 \\
-2.121297 \\
-.3732913 \\
.0412964 \\
.0326451\end{array}$ & $\begin{array}{r}.5278302 \\
.1620611 \\
-1.344642 \\
13.02924 \\
5.19636 \\
-3.772652 \\
-1.642437 \\
.4674994 \\
-.0059582 \\
.033304\end{array}$ & $\begin{array}{r}-.0966435 \\
-.0379193 \\
-2.19062 \\
-2.430641 \\
2.234757 \\
.7628269 \\
-.4788595 \\
-.8407907 \\
.0472546 \\
-.0006589\end{array}$ & $\begin{array}{r}.2366873 \\
.0827673 \\
2.292964 \\
2.734697 \\
2.194235 \\
.6553395 \\
1.395866 \\
.8251832 \\
.059471 \\
.0127717\end{array}$ \\
\hline
\end{tabular}

Hausman Test to fix on Fixed effects or Random effects

- hausman fe re

$\mathrm{b}=$ consistent under Ho and $\mathrm{Ha}$; obtained from xtreg $\mathrm{B}=$ inconsistent under $\mathrm{Ha}$, efficient under Ho; obtained from xtreg

Test: Ho: difference in coefficients not systematic

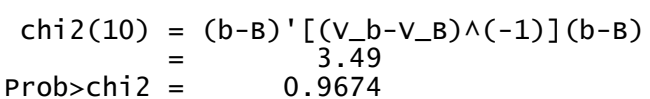

(ii) Test of Random Effects Versus Pooled OLS

\section{(a) Model 1}

- xttest0

Breusch and Pagan Lagrangian multiplier test for random effects

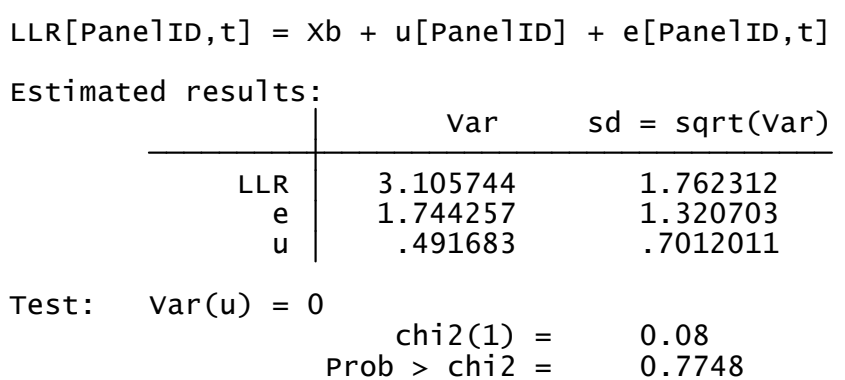


(b) Model 2

- xttest0

Breusch and Pagan Lagrangian multiplier test for random effects

PR30days $[$ Pane1ID,$t]=x b+u[P a n e 1 I D]+e[P a n e 1 I D, t]$

Estimated results:

\begin{tabular}{r|rc} 
& var & sd $=$ sqrt(Var) \\
\hline PR30days & 45.08994 & 6.714905 \\
$\mathrm{e}$ & 10.74799 & 3.278412 \\
$\mathrm{u}$ & 37.86239 & 6.153242
\end{tabular}

Test: $\operatorname{var}(u)=0$

$\begin{aligned} \operatorname{chi}(1)= & 37.03 \\ \text { Prob }>\text { chi2 }= & 0.0000\end{aligned}$

- xttest0

Breusch and Pagan Lagrangian multiplier test for random effects

WOF $[$ PanelID, t $]=X b+u[$ PanelID $]+\mathrm{e}[$ PanelID, $\mathrm{t}]$

Estimated results:

\begin{tabular}{r|rr} 
& var & sd $=$ sqrt(Var) \\
\hline WOF & 7.281104 & 2.698352 \\
$\mathrm{e}$ & 1.548142 & 1.244244 \\
$\mathrm{u}$ & 0 & 0
\end{tabular}

Test: $\quad \operatorname{var}(\mathrm{u})=0$

$$
\begin{aligned}
& \operatorname{chi2}(1)=0.63 \\
& \text { Prob }>\text { chi2 }=0.4289
\end{aligned}
$$

\section{Testing Assumptions of OLS}

i. Multicollinearity

\begin{tabular}{l|rr} 
vif \\
Variable & VIF & 1 VIF \\
\hline OPEXP & 2.81 & 0.356007 \\
LnTA & 2.79 & 0.358582 \\
FAge & 2.08 & 0.481396 \\
PRODUCTIVITY & 1.84 & 0.542993 \\
OUTLOAN & 1.71 & 0.584637 \\
INFLATION & 1.64 & 0.609159 \\
WomBor & 1.52 & 0.656121 \\
Ch_Loan & 1.42 & 0.705234 \\
LEV & 1.39 & 0.719815 \\
Ch_GNI & 1.37 & 0.731036 \\
\hline Mean VIF & 1.86 &
\end{tabular}


ii. Heteroskedasticity Test

a. Model 1

- hettest

Breusch-Pagan / Cook-Weisberg test for heteroskedasticity

Ho: Constant variance

variables: fitted values of LLR

$\operatorname{chi2}(1)=6.29$

Prob $>$ chi2 $=0.0121$

. hettest

Breusch-Pagan / Cook-Weisberg test for heteroskedasticity Ho: Constant variance

variables: fitted values of PR30days

$\operatorname{chi2}(1)=30.96$

Prob $>$ chi2 $=0.0000$

b. Model 3

- hettest

Breusch-Pagan / Cook-Weisberg test for heteroskedasticity Ho: Constant variance

variables: fitted values of woF

$\operatorname{chi2}(1)=7.84$

Prob $>$ chi2 $=0.0051$ 